\title{
Isoenzymes as an aid to clarify the taxonomy of French elms
}

\author{
N. MACHON*, M. LEFRANC, I. BILGER† AND J.-P. HENRY \\ *Laboratoire d'Evolution et de Systèmatique des Végétaux, Bât. 362, Université Paris-Sud-CNRS (U.R.A. 1492), F-91405 \\ Orsay Cedex and †CEMAGREF (French Institute of Agricultural and Environmental Engineering Research), Domaine des \\ Barres, F-45290 Nogent-sur-Vernisson, France
}

\begin{abstract}
Isoenzymes were used to assess the genetic variability of the three French species of elms: Ulmus laevis Pall. from section Blepharocarpus, Ulmus minor Mill. and Ulmus glabra Huds. from section Ulmus. Three main results were obtained. The first was that these species are segmental tetraploids, i.e. they behave as tetraploids for part of the genome and as diploids for the rest of it. Secondly, we found that there exists a large amount of polymorphism in the French species of elm. Thirdly, Ulmus laevis produces isozyme patterns which differentiate it from species in section Ulmus. These results contribute to a clarification of the taxonomy of elms.
\end{abstract}

Keywords: genetic diversity, isoenzymes, polymorphism, taxonomy of elms, tetraploidy, Ulmus sp.

\section{Introduction}

The taxonomy of European elms is notoriously difficult. There are many reasons for this situation. Firstly, there are very few floral characters which discriminate between taxa. The fruits provide some useful traits to discriminate between major groups but they are not sufficient for more detailed discrimination. Also they are available for a short time only on mature trees and they are not found in many herbarium collections. Therefore, vegetative characters such as leaf shape, bark and cork features, and tree habit, are the main characters used to discriminate between the taxa (e.g. Jobling \& Mitchell, 1974). These traits are very plastic; they vary even on a single tree during an individual lifetime depending on age and environmental conditions. Herbarium samples do not supply information on the shape of the tree. Moreover, these traits can only be used with mature and nonpollarded trees (which, with Dutch Elm disease, are becoming scarce). Juvenile trees, which are in the majority in many populations, are very difficult to classify.

In addition to these technical difficulties, there has been extensive hybridization between taxa, which followed a phase of differentiation in several presumed refugia during the last glacial period (Richens, 1983, chap. 3). Moreover, some elms, especially field elms (Ulmus minor Mill. sensu Richens) and hybrid elms

*Correspondence.
( $U . \times$ hollandica Mill. sensu lato), have been extensively propagated by humans since prehistoric times (Richens, 1983). Cuttings were sometimes transported over large distances resulting in an intricate geographical pattern of many distinctive interlocked clones of varying size (see Richens, 1983 for a review of English populations).

Finally, botanists have burdened themselves with the rules of botanical nomenclature and the problems in applying them to recalcitrant material such as elm. More than 70 binomial names have been used for European elms, and there are many more intraspecific combinations. The same binomial is often used with a different meaning from one author to another.

In modern times, European botanists have used various taxonomic systems which lie between two extremes based on studies of English populations. One extreme position assumes the existence of many species and interspecific hybrids as described by Melville $(1975,1978)$. For British elms of the section Ulmus, he assumed the existence of six species, some 'almost hybridized out of existence', and 11 interspecific hybrids, involving up to four species. He carried out less investigation into continental European elms but recognized another species in the eastern Mediterranean region ( $U$. canescens Melville). According to Richens (1983, p. 86), 'If the same approach were applied to the European elms as a whole, it would be difficult, without inconsistency of treatment, to get away with less than 20 species'. At the 
other extreme, Richens (1968) pooled all the European elms of the section Ulmus in two species: $U$. glabra Huds. and $U$. minor Mill. sensu latissimo, with one interspecific hybrid $(U . \times$ hollandica Mill. s.l.). Discussions concerning these two taxonomic treatments have been presented by Melville (1978) and Richens (1980).

For 50 years, very few studies have been concerned with the variability of French elm populations. Richens \& Jeffers $(1975,1978)$ made a biometrical survey of elms of northern France. A taxonomic revision of elms in Anjou was carried out by Corillion (1991), using classical taxonomic methods; with a narrow-species concept, he assumed five species in this region (including the $U$. laevis Pallas species, which is quite different from the others and which belongs to the section Blepharocarpus Dumort.). In recent times, most French Floras and catalogues (e.g. Guinochet \& Vilmorin, 1973; Grenier, 1992; Kerguelen, 1993) merely follow the taxonomic treatment of Tutin in Flora Europaea (1st edn, 1964), assuming four species in western Europe: $U$. laevis Pall. from the section Blepharocarpus, and $U$. glabra Huds., $U$. minor Mill. and $U$. procera Salisb. $(=U$. minor var. vulgaris (Aiton) Richens, see Richens, 1968) from the section Ulmus; but there is considerable disagreement and problems concerning the presence and frequency of this last species in France.

During the years 1970-80, the second epidemic of Dutch elm disease destroyed most mature trees in France as in other countries. The French Ministry for Agriculture has initiated a programme for the conservation of genetic resources including the search for and collection of healthy French elms and research. In the framework of this programme, we studied the genetic diversity of the elm collection. In this article, we present results obtained on allozyme diversity and we discuss implications for the systematics of French elms. Isoenzymatic data have been previously reported by Pearce \& Richens (1977) and Richens \& Pearce (1984) for European elms, with only one system, and by Sherman-Broyles et al. (1992) for the American species $U$. crassifolia Nutt. Wiegrefe (1992) and Wiegrefe et al. (1993) used molecular tools to study the genetic diversity of the genus Ulmus. In this paper, the taxonomic treatment of Richens is adopted (assuming four taxa: $U$. laevis, $U$. glabra, $U$. minor and the hybrids between $U$. glabra and $U$. minor. $U . \times$ hollandica) because our vegetative material, consisting mainly of young trees from cuttings, did not permit us to distinguish more precise species.

\section{Materials and methods}

In the framework of the programme led by the CEMAGREF (French Institute of Agricultural and Environmental Engineering Research), aimed at preservimg the genetic diversity of French elms, a thorough survey was carried out in five regions (Table 1) to list every mature and healthy elm tree (diameter of the trunk more than $15 \mathrm{~cm}$ and height more than $1.3 \mathrm{~m}$ ). Most trees were cloned by cuttings which were planted in a conservatory plantation at Nogent-sur-Vernisson (Loiret, France) comprising about 270 trees in 1993.

The plant material used for our study consisted of samples taken from all the trees in the conservatory plantation and other samples taken from other trees in their natural environment. Field determinations of species were made by the persons who collected the samples. We worked on 298 trees: 151 U. minor Mill., 48 U. glabra Huds., 74 U. laevis Pall. and 25 trees which have been recorded as putative hybrids between $U$. minor and $U$. glabra, $(U . \times$ hollandica Mill. sensu lato). Additionally, seedlings of offspring of three $U$.

Table 1 Sample sizes $(N)$ for each region and species of elm

\begin{tabular}{|c|c|c|c|}
\hline Regions & $N$ & Species & $N$ \\
\hline Nord-pas de Calais & 26 & $\begin{array}{l}U . \text { minor } \\
U . \text { glabra } \\
U . \text { laevis } \\
U . \times \text { hollandica }\end{array}$ & $\begin{array}{r}20 \\
0 \\
6\end{array}$ \\
\hline Ile de France & 30 & $\begin{array}{l}U . \text { minor } \\
U . \text { glabra } \\
U . \text { laevis } \\
U . \times \text { hollandica }\end{array}$ & $\begin{array}{r}18 \\
2 \\
8 \\
2\end{array}$ \\
\hline Normandie & 65 & $\begin{array}{l}U . \text { minor } \\
U . \text { glabra } \\
U . \text { laevis } \\
U . \times \text { hollandica }\end{array}$ & $\begin{array}{r}43 \\
2 \\
0 \\
20\end{array}$ \\
\hline Poitou & 64 & $\begin{array}{l}U . \text { minor } \\
U . \text { glabra } \\
U . \text { laevis } \\
U . \times \text { hollandica }\end{array}$ & $\begin{array}{r}59 \\
0 \\
5 \\
0\end{array}$ \\
\hline East of France & 113 & $\begin{array}{l}U . \text { minor } \\
U . \text { glabra } \\
U . \text { laevis } \\
U . \times \text { hollandica }\end{array}$ & $\begin{array}{r}11 \\
44 \\
55 \\
3\end{array}$ \\
\hline Total & 298 & $\begin{array}{l}U . \text { minor } \\
\text { U. glabra } \\
\text { U. laevis } \\
U . \times \text { hollandica }\end{array}$ & $\begin{array}{r}151 \\
48 \\
74 \\
25\end{array}$ \\
\hline
\end{tabular}


minor trees (open pollinated) were checked to confirm the inheritance of the electrophoretic patterns we obtained. As the trees of the conservatory plantation were immature, this study was conducted on trees from Orsay (Essonne, France).

An American $\operatorname{Elm}(U$. americana L. sect. Blepharocarpus) from the 'Arboretum des Barres' (Loiret, France) was also studied.

For the enzyme extraction, young leaf tissue was crushed with a mortar and pestle in liquid nitrogen and enzymes were extracted with a cysteine buffer: $1 \mathrm{~g}$ of leaf was ground with $3 \mathrm{~mL}$ of $10 \mathrm{~mm}$ Tris $\mathrm{Cl}^{-} \mathrm{pH} 7.2$, $4 \mathrm{~mm}$ dithioerythritol, $5 \mathrm{~mm}$ cysteine and 10 per cent polyvinylpyrrolidone (soluble PVP). After centrifugation $\left(3000 \mathrm{~g}\right.$ for $20 \mathrm{~min}$ ) extracts were stored at $-70^{\circ} \mathrm{C}$ until used for electrophoresis. Horizontal starch gels were composed of 13 per cent starch. Catalase, CAT (E.C. 1.11.1.6), anodic peroxidase, PRXA (E.C. 1.11.1.7) and phosphoglucoisomerase, PGI (E.C. 5.3.1.9) were resolved using a lithium-borate electrode and gel buffer adapted from Soltis \& Soltis (1990). Malate dehydrogenase, MDH (E.C. 1.1.1.37), phosphoglucomutase, PGM (E.C. 5.4.2.2) and 6-phosphogluconate dehydrogenase, 6PGD (E.C. 1.1.1.44) were resolved on an histidine gel and electrode buffer also adapted from Soltis \& Soltis (1990) and cathodic peroxidase, PRXC (E.C. 1.11.1.7) was resolved using a Tris maleic gel and electrode buffer adapted from Shaw \& Prasad (1970).

Measures of allozyme diversity were estimated by the software 'BIosys-1' (Swofford \& Selander, 1981). Nei's genetic diversity $H_{\mathrm{T}}(\mathrm{Nei}, 1973)$ was calculated from all the loci but Nei's genetic distances (Nei, 1972) were only calculated from the systems whose behaviour was disomic.

\section{Results}

The seven systems we studied revealed eight loci. For some of the systems (CAT, 6PGD, PRXC and PGI), the patterns we obtained suggest disomic inheritance. The 6PGD system, for example (Fig. 1), shows typical dimeric patterns (one or three bands) assuming a disomic system.

For the other systems (PGM, PRXA and MDH), the number of bands and the variability of their intensity seem to be typical of a tetrasomic system. PGM patterns, for example (Fig. 2), consist of one to four bands of variable intensity. All the patterns found for this system may be explained on the basis of tetrasomic inheritance. The resolution of the PRXA gels was unclear but the patterns suggest that this system has the same behaviour as the PGM system. For $\mathrm{MDH}$, the dimeric banding patterns (Fig. 3) showed variable intensity, which is easily explained by tetrasomic inheritance.

Table 2 gives the results for the three trees from Orsay and their offspring. The patterns are often monomorphic and provide little evidence to elucidate the inheritance system in these species.

The trees sampled for this study were very polymorphic for isoenzyme patterns. In particular, $U$. minor presented a high mean number of alleles per locus (Table 3 ) whereas $U$. glabra seemed to be mono-
Fig. 1 Photograph and zymogram of 6PGD phenotypes.
6PGD

Phenotypes

Genotypes

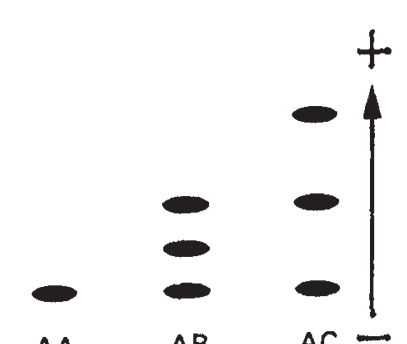

AA

$A B$

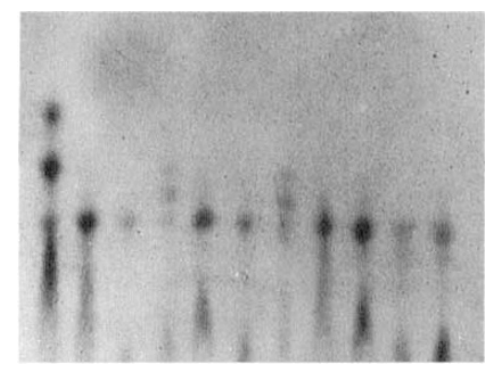

Fig. 2 Photograph and zymogram of
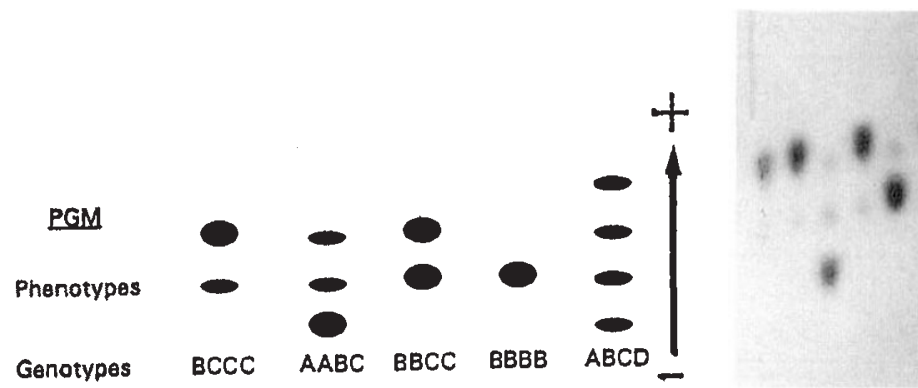
morphic for the 6PGD system. U. laevis showed the least polymorphism (a mean of 1.9 alleles per locus) and was monomorphic for PRXA slow and fast loci and for the catalase system.

On the basis of these banding patterns, Nei's genetic diversity is higher for $U$. glabra, $U$. minor and $U$. $\times$ hollandica compared with $U$. laevis.

Allele frequencies are shown in Table 4 and the results of a $\chi^{2}$ test to compare the allele frequencies

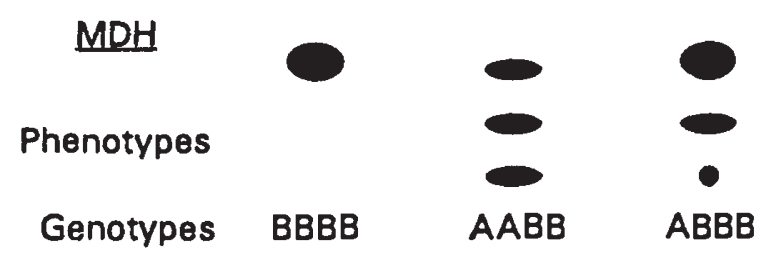

between the different species are presented in Table 5 . The distributions of alleles were completely different between $U$. minor and $U$. glabra. We did find, however, similarities between $U$. minor and the intermediate forms and also between $U$. glabra and the intermediate forms.

A large difference was found between $U$. laevis and the other species for the PRXA system (Fig. 4). For the species $U$. glabra and $U$. minor, this system is interpreted as two independent tetraploid loci, both presenting four different alleles. $U$. laevis did not show any of the bands found in the other elm species at the slower locus. At the faster locus, all the $U$. laevis plants only presented a thin band at the level of the third allele in the other elms and, additionally, a characteristic thick band below those found in the other elms. The same phenotype was also observed for an elm from the same section: the $U$. americana tree from the 'Arbore-

Fig. 3 Zymogram of MDH phenotypes.

Table 2 Analysis by electrophoresis of the offspring of three Ulmus minor mother trees for PGM, MDH and $P R X A$ fast loci

\begin{tabular}{|c|c|c|c|}
\hline Locus & Genotype of the mother tree & $\begin{array}{l}\text { Size of the } \\
\text { offspring (seedlings) }\end{array}$ & Phenotype of the offspring \\
\hline$P G M$ & $\begin{array}{l}\text { Tree no. } 1: \text { undetermined } \\
\text { Tree no. 2: undetermined } \\
\text { Tree no. 3: undetermined }\end{array}$ & $\begin{array}{r}8 \\
12 \\
13\end{array}$ & $\begin{array}{l}\text { Same phenotype for all the seedlings. } \\
\text { One band at the B level and one band at } \\
\text { the } C \text { level, both having same intensity. }\end{array}$ \\
\hline$M D H$ & $\begin{array}{l}\text { Tree no. } 1: \text { undetermined } \\
\text { Tree no. } 2: \text { undetermined } \\
\text { Tree no. 3: undetermined }\end{array}$ & $\begin{array}{r}8 \\
12 \\
13\end{array}$ & $\begin{array}{l}\text { Same phenotype for all the seedlings. } \\
\text { One thin band at the A level, one weak } \\
\text { band at the B level. }\end{array}$ \\
\hline \multirow[t]{3}{*}{$\begin{array}{l}P R X A \\
\text { fast locus }\end{array}$} & Tree no. 1: $A A C C$ & $\begin{array}{r}8 \\
=5 \\
\text { and } 3\end{array}$ & $\begin{array}{l}\text { One band } \mathrm{A} \text {, one band } \mathrm{D} \text {, same intensity. } \\
\text { One band } \mathrm{C} \text {, one band } \mathrm{D} \text {, same intensity. }\end{array}$ \\
\hline & Tree no. 2: $A A D D$ & $\begin{array}{r}12 \\
=2 \\
4 \\
4 \\
1 \\
\text { and } 1\end{array}$ & $\begin{array}{l}\text { One band } A \text {, one band } C \text {, same intensity. } \\
\text { One band D. } \\
\text { One band } A \text {, one band D, same intensity. } \\
\text { One band } A \text {, one band B, same intensity. } \\
\text { One band C, one band D, same intensity. }\end{array}$ \\
\hline & Tree no. 3: $D D D D$ & $\begin{array}{r}13 \\
=6 \\
\text { and } 7\end{array}$ & $\begin{array}{l}\text { One band } \mathrm{A} \text {, one band } \mathrm{D} \text {, same intensity. } \\
\text { One band } \mathrm{C} \text {, one band } \mathrm{D} \text {, same intensity. }\end{array}$ \\
\hline
\end{tabular}

Table 3 Nei's genetic diversity for eight loci in the different species of elm

\begin{tabular}{lcccc}
\hline \multicolumn{1}{c}{ Species } & $\begin{array}{c}\text { Mean sample } \\
\text { size per locus }\end{array}$ & $\begin{array}{c}\text { Mean no. of } \\
\text { alleles per locus }\end{array}$ & Polymorphic loci $(\%)$ & $\begin{array}{c}\text { Nei's genetic } \\
\text { diversity } H_{\mathrm{T}}\end{array}$ \\
\hline$U$. minor & 114.8 & $3.0(0.3)$ & 100 & $0.330(0.066)$ \\
$U$. glabra & 34.9 & $2.6(0.4)$ & 75.0 & $0.395(0.089)$ \\
$U$. laevis & 54.9 & $1.9(0.2)$ & 87.0 & $0.247(0.077)$ \\
$U . \times$ hollandica & 19.9 & $2.9(0.4)$ & 87.5 & $0.366(0.097)$ \\
\hline
\end{tabular}

Standard errors are in parentheses. 
Table 4 Allele frequencies for eight polymorphic loci for each species of elm

\begin{tabular}{|c|c|c|c|c|c|}
\hline Allele & & $U$. minor & $U . \times$ hollandica & U. glabra & U. laevis \\
\hline \multirow[t]{5}{*}{ PRXAs. } & $N$ & 0 & 0 & 0 & 1 \\
\hline & 1 & 0.05 & 0.06 & 0.15 & 0 \\
\hline & 2 & 0.12 & 0.19 & 0.59 & 0 \\
\hline & 3 & 0.69 & 0.56 & 0.24 & 0 \\
\hline & 4 & 0.14 & 0.19 & 0.02 & 0 \\
\hline No. & & 132 & 18 & 26 & 74 \\
\hline \multirow[t]{5}{*}{$P R X A f$} & 1 & 0 & 0 & 0 & 0.75 \\
\hline & 2 & 0.01 & 0.16 & 0.06 & 0 \\
\hline & 3 & 0.50 & 0.32 & 0.39 & 0 \\
\hline & 4 & 0.47 & 0.41 & 0.36 & 0.25 \\
\hline & 5 & 0.02 & 0.11 & 0.19 & 0 \\
\hline No. & & 131 & 23 & 48 & 33 \\
\hline \multirow[t]{3}{*}{$6 P G D$} & 1 & 0.91 & 0.98 & 1 & 0.93 \\
\hline & 2 & 0.08 & 0.02 & 0 & 0.07 \\
\hline & 3 & 0.01 & 0 & 0 & 0 \\
\hline No. & & 92 & 21 & 33 & 51 \\
\hline \multirow[t]{4}{*}{$P G M$} & 1 & 0.06 & 0.17 & 0.10 & 0 \\
\hline & 2 & 0.45 & 0.34 & 0.15 & 0.09 \\
\hline & 3 & 0.45 & 0.32 & 0.20 & 0.52 \\
\hline & 4 & 0.04 & 0.17 & 0.55 & 0.39 \\
\hline No. & & 137 & 23 & 44 & 71 \\
\hline \multirow[t]{3}{*}{$P G I$} & 1 & 0.10 & 0.05 & 0.04 & 0.86 \\
\hline & 2 & 0.87 & 0.86 & 0.96 & 0.14 \\
\hline & 3 & 0.03 & 0.09 & 0 & 0 \\
\hline No. & & 134 & 22 & 46 & 71 \\
\hline \multirow[t]{2}{*}{$P R X C$} & 1 & 0.05 & 0.11 & 0.18 & 0.92 \\
\hline & 2 & 0.95 & 0.89 & 0.82 & 0.08 \\
\hline No. & & 124 & 19 & 22 & 24 \\
\hline \multirow[t]{2}{*}{$C A T$} & 1 & 0.89 & 0.93 & 0.76 & 1 \\
\hline & 2 & 0.11 & 0.07 & 0.24 & 0 \\
\hline No. & & 59 & 14 & 27 & 45 \\
\hline \multirow[t]{2}{*}{$M D H$} & 1 & 0.20 & 0.13 & 0.57 & 0.59 \\
\hline & 2 & 0.80 & 0.87 & 0.43 & 0.41 \\
\hline No. & & 109 & 19 & 33 & 29 \\
\hline
\end{tabular}

No. is the sample size. We assume that Ulmus laevis trees have a null allele $(N)$ at the slower locus of the PRXA system and that the thin band is allele number 1 of the second locus (i.e. the genotypes are always $A A A D$, see

Fig. 4).

tum des Barres' (Nogent-sur-Vernisson, France) but never for the other European elms ( $U$. glabra and $U$. minor). No intermediate form was observed between the characteristics of $U$. laevis and those of the others.

The phenogram for species based on the calculations for disomic loci is shown in Fig. 5. One cluster was composed of $U$. glabra, $U$. minor, and
$U . \times$ hollandica which was intermediate between $U$. glabra and $U$. minor. The genetic distances within this cluster are very low. The other cluster only consisted of the $U$. laevis group and was separated at a distance of 0.71 unit.

\section{Discussion and conclusion}

\section{Inheritance and tetraploidy}

The electrophoretic patterns that we obtained suggest disomic inheritance for four loci in our study ( $6 P G D$, $P G I, P R X C$ and $C A T$ ) and tetrasomic inheritance for the other four loci (PRXA slow and fast, PGM and $M D H)$ based on observations from 298 trees.

In the PGM system, for example (Fig. 2), individuals can produce one to four bands. Three arguments lead us to the conclusion that inheritance is tetrasomic. (i) If many individuals possess three or four bands, it is possible that two or more loci are involved. However, as many individuals produce only one band, this would assume that null alleles exist at the loci in the homozygous state. A more simple explanation is that only one tetrasomic locus exists. (ii) When one individual possesses three bands, one of them is always more intense than the two others, indicating that the genotype could be $A A B C$ type. (iii) Almost all the combinations of the four alleles are found in our sample (Table 6).

For the $P R X A$ loci, the arguments for tetrasomic inheritance are almost the same but the phenotypes are not well defined and it is difficult to ascertain the exact genotypes and patterns of inheritance. We assume that they are like the PGM system.

For the MDH system (Fig. 3), the arguments are different. This enzyme is usually dimeric. The trees of our sample possess one or three bands with variable intensity. A hypothesis of tetrasomic inheritance would explain all the zymograms obtained: (i) homozygous trees give only one spot, and (ii) heterozygous trees give three more or less intense spots depending on whether they are simplex digenic $(A B B B$ or $A A A B)$ or duplex digenic $(A A B B)$.

Our interpretation of the patterns we obtained suggests that elm trees are segmental allotetraploids. These species could derive from doubling the chromosomes of an interspecific hybrid whose parents were genetically close so that their chromosomes retain a high degree of homology, but which may differ by small structural changes. The doubling could also originate in an autotetraploidization of an Ulmus ancestor. We may assume that this occurred a long time ago followed by incomplete diploidization. This phenomenon has already been described in animal groups (Waples, 
Table 5 Results of $\chi^{2}$ tests comparing allele frequencies between the different species of elm

\begin{tabular}{|c|c|c|c|c|c|c|}
\hline Locus & & $\begin{array}{l}U . m . \text { and } \\
\text { U.g. }\end{array}$ & $\begin{array}{l}U . m . \text { and } \\
\text { U.l. }\end{array}$ & $\begin{array}{l}\text { U.g. and } \\
\text { U.l. }\end{array}$ & $\begin{array}{c}U . m . \text { and } \\
U . \times \text { hollandica }\end{array}$ & $\begin{array}{c}\text { U.g. and } \\
U . \times \text { hollandica }\end{array}$ \\
\hline PRXAs. & $\begin{array}{l}\text { d.f. } \\
\chi^{2} \\
P\end{array}$ & $\begin{array}{c}3 \\
152 \\
0.0001\end{array}$ & $\begin{array}{c}4 \\
824 \\
0.0001\end{array}$ & $\begin{array}{l}4 \\
400 \\
0.0001\end{array}$ & $\begin{array}{l}3 \\
6.02 \\
0.1105\end{array}$ & $\begin{array}{l}3 \\
45 \\
0.0001\end{array}$ \\
\hline PRXA f. & $\begin{array}{l}\text { d.f. } \\
\chi^{2} \\
P\end{array}$ & $\begin{array}{l}3 \\
95 \\
0.0001\end{array}$ & $\begin{array}{c}4 \\
573 \\
0.0001\end{array}$ & $\begin{array}{c}4 \\
338 \\
0.0001\end{array}$ & $\begin{array}{l}3 \\
67 \\
0.0001\end{array}$ & $\begin{array}{l}3 \\
11 \\
0.0142\end{array}$ \\
\hline $6 P G D$ & $\begin{array}{l}\text { d.f. } \\
\chi^{2} \\
P\end{array}$ & $\begin{array}{l}2 \\
12 \\
0.0022\end{array}$ & $\begin{array}{l}2 \\
1.44 \\
0.4867\end{array}$ & $\begin{array}{l}1 \\
9 \\
0.0021\end{array}$ & $\begin{array}{l}2 \\
3.97 \\
0.1375\end{array}$ & $\begin{array}{l}1 \\
3.17 \\
0.0749\end{array}$ \\
\hline$P G M$ & $\begin{array}{l}\text { d.f. } \\
\chi^{2} \\
P\end{array}$ & $\begin{array}{c}3 \\
263 \\
0.0001\end{array}$ & $\begin{array}{c}3 \\
238 \\
0.0001\end{array}$ & $\begin{array}{l}3 \\
65 \\
0.0001\end{array}$ & $\begin{array}{l}3 \\
41 \\
0.0001\end{array}$ & $\begin{array}{l}3 \\
36 \\
0.0001\end{array}$ \\
\hline$P G I$ & $\begin{array}{l}\text { d.f. } \\
\chi^{2} \\
P\end{array}$ & $\begin{array}{l}2 \\
12 \\
0.0026\end{array}$ & $\begin{array}{c}2 \\
462 \\
0.0001\end{array}$ & $\begin{array}{c}1 \\
299 \\
0.0001\end{array}$ & $\begin{array}{l}2 \\
10 \\
0.0074\end{array}$ & $\begin{array}{l}2 \\
17 \\
0.0002\end{array}$ \\
\hline$P R X C$ & $\begin{array}{l}\text { d.f. } \\
\chi^{2} \\
P\end{array}$ & $\begin{array}{l}1 \\
19 \\
0.0001\end{array}$ & $\begin{array}{c}1 \\
391 \\
0.0001\end{array}$ & $\begin{array}{c}1 \\
101 \\
0.0001\end{array}$ & $\begin{array}{l}1 \\
3.41 \\
0.0649\end{array}$ & $\begin{array}{l}1 \\
1.91 \\
0.1666\end{array}$ \\
\hline$C A T$ & $\begin{array}{l}\text { d.f. } \\
\chi^{2} \\
P\end{array}$ & $\begin{array}{l}1 \\
10 \\
0.0017\end{array}$ & $\begin{array}{l}1 \\
21 \\
0.0001\end{array}$ & $\begin{array}{c}1 \\
48 \\
0.0001\end{array}$ & $\begin{array}{l}1 \\
0.74 \\
0.3907\end{array}$ & $\begin{array}{l}1 \\
7 \\
0.0078\end{array}$ \\
\hline$M D H$ & $\begin{array}{l}\text { d.f. } \\
\chi^{2} \\
P\end{array}$ & $\begin{array}{l}1 \\
67 \\
0.0001\end{array}$ & $\begin{array}{l}1 \\
68 \\
0.0001\end{array}$ & $\begin{array}{l}1 \\
0.08 \\
0.7744\end{array}$ & $\begin{array}{l}1 \\
1.95 \\
0.1629\end{array}$ & $\begin{array}{l}1 \\
38 \\
0.0001\end{array}$ \\
\hline
\end{tabular}

U. g., Ulmus glabra; U. l., U. laevis; U. m., U. minor. Bold indicates nonsignificance.

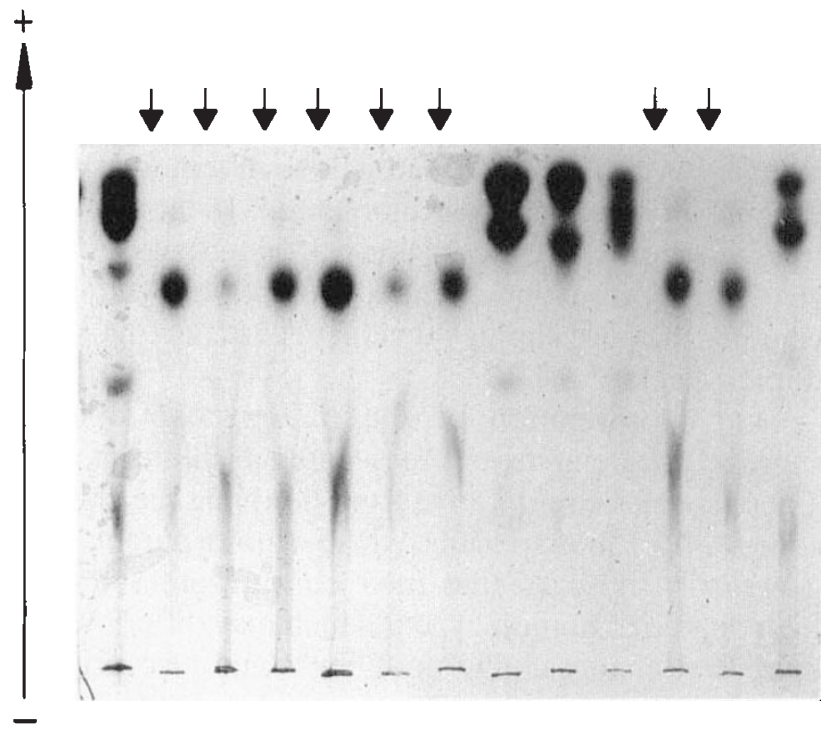

Fig. 4 Photograph of isoenzyme phenotypes for the PRXA. system. Arrows show the Ulmus laevis phenotypes among all the French species of elm.
1988) and also in many plant groups (Stebbins, 1971). Wild olive trees (Olea europaea L.) for example seem to have the same behaviour (Ouazzani et al., 1993).

The results (Table 2) for the offspring of the three mother trees from Orsay do not produce clear-cut evidence about the inheritance of the systems for many reasons. (i) For PGM and $\mathrm{MDH}$, the patterns were monomorphic and the genotypes of the mother trees were missing; and (ii) for all the systems tested on the offspring, electrophoresis was performed on seedlings. It is possible that the expressions of genes are different in young plantlets and in the leaves of an adult tree. The tetraploid patterns could be the result of the expression of two loci (isoloci) placed on two homeologous pairs of chromosomes with each locus showing independent disomic inheritance as in the case of Lotus (Raelson et al., 1989). It is possible that for the elm trees, one of these two loci does not express in young seedlings, producing disomic inheritance. The answer to this problem would be to study the adult offspring of selected genotypes, but we do not have such material. 
Fig. 5 Phenogram of UPGMA cluster analysis based on Nei's genetic distances between the different French species of elm.

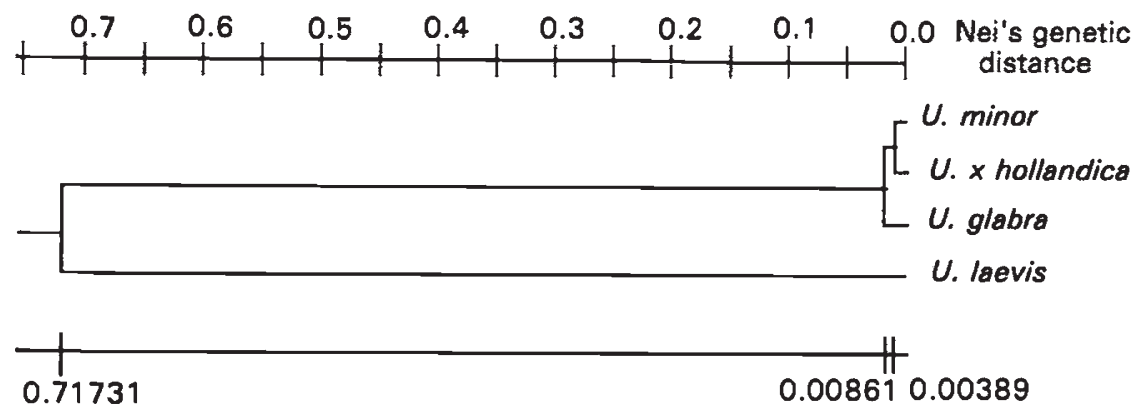

Table 6 Number $(N)$ of elms with the different genotypes found for the PGM system

\begin{tabular}{lrcccccr}
\hline Genotypes & $N$ & Genotypes & $N$ & Genotypes & $N$ & Genotypes & $N$ \\
\hline$A A A A$ & 1 & $A B B D$ & 1 & $B B B B$ & 13 & $B C C D$ & 2 \\
$A A B B$ & 8 & $A B C C$ & 6 & $B B B C$ & 15 & $B C D D$ & 5 \\
$A A B C$ & 9 & $A B C D$ & 3 & $B B B D$ & 2 & $C C C C$ & 14 \\
$A A C C$ & 8 & $A B D D$ & 1 & $B B C C$ & 71 & $C C D D$ & 4 \\
$A A D D$ & 2 & $A C D D$ & 1 & $B B D D$ & 15 & $C D D D$ & 1 \\
$A B B C$ & 15 & $A D D D$ & 3 & $B C C C$ & 29 & $D D D D$ & 21 \\
\hline
\end{tabular}

Few karyological studies have been carried out on these elm species. It is known that they all possess $2 n=28$ chromosomes except $U$. americana which has $2 n=56$ (Fedorov, 1974) while no species in the Ulmaceae family possesses 14 chromosomes. Leliveld (1934), observing meiosis of elm trees, saw only bivalents. Nevertheless, this does not preclude tetrasomic inheritance in some systems because Dawson (1941) demonstrated tetrasomic inheritance of cyanogenesis in Lotus when only bivalents were observed.

\section{Comparison of the different species}

The allele frequencies obtained indicate that each species possesses its own characteristic distribution of alleles. In our sample, $U$. minor and $U$. glabra had the same alleles, although with different distributions, and the genetic distances between them were very low. Intermediate forms (putative $U . \times$ hollandica) had an intermediate distribution. This indicates that the morphological continuum existing between the two extreme species is the expression of a true genetic continuity. Numerous authors, in the framework of selection of clones resistant to Dutch Elm disease, have published results of interspecific crosses (Townsend, 1975; Mittempergher \& La Porta, 1991; and others reviewed by Heybroek, 1992). They showed that $U$. glabra and $U$. minor can crossbreed freely and that the hybrids are completely fertile. Backcrossing can give a range of possible intermediates which probably occur in overlapping distribution zones.
The results we obtained for $U$. laevis trees showed that this species is very close to the other elm species in many respects: they have the same number of chromosomes, they possess the same tetraploid structure, with the same diploidized systems, and for several systems, the difference found in the allele frequencies between $U$. laevis and the other species is not higher than that observed between $U$. minor and $U$. glabra. On the other hand, differences in the expression of the PRXA system set them apart. The results we obtained for the PRXA system of $U$. laevis can be interpreted in different ways depending on whether the characteristic thick band is attributed to one or the other locus existing in the other species of elms. $U$. laevis possesses a specific allele and/or a null allele for the slower locus. As long as no variability is found for this system it is impossible to determine the right interpretation. Nevertheless, the genetic distance calculated (Fig. 5) reflects the large difference existing between this elm species and the others. Opinions are divided, however, about the ability of $U$. laevis to crossbreed with the elms of the Ulmus section. Heybroek (1992) notes that Klotzsch (1855) obtained 'extremely vigorous hybrids' between $U$. campestris (syn. minor) and $U$. effusa (syn. laevis). More recent authors (Townsend, 1975; Mittempergher \& La Porta, 1991) have not been able to obtain such hybrids in controlled crosses. The results we obtained could be a consequence of a genetic divergence between the different sections and sexual isolation of $U$. laevis in relation to the other French species. 


\section{Genetic diversity}

Generally, elm trees are more diverse than other tree species in spite of the Dutch Elm disease which has severely restricted the population size: calculations for Nei's genetic diversity gave 0.258 for Castanea sativa Mill. (personal observation) and 0.275 for Quercus petraea (Kremer \& Petit, 1993) in similar studies.

In our sample, the genetic diversity was higher for $U$. glabra than for the other French elm species. This result is in agreement with those found by Richens \& Pearce (1984) concerning isoperoxidase variation. It can be explained by the fact that $U$. glabra is a sexually reproducing tree, native to western Europe, whereas $U$. minor has always been mainly asexually propagated.

$U$. laevis showed a lower genetic diversity than the other species. This result probably reflects its sexual isolation from the other French elms and possible drift caused by the disastrous effects of Dutch Elm disease.

In conclusion, this paper reports the first analysis of genetic diversity in French elms. At the isozymic level, the variability is rather high compared with other tree species. Because of the paucity of taxonomic characters, other methods have to be used to clarify the systematics of the genus Ulmus. Even though the number of markers used is low, the results of our study clearly demonstrate the unambiguous genetic distinction of the two sections but the differences between $U$. minor and $U$. glabra and the intermediate $U . \times$ hollandica are so small that they should be regarded as belonging to a common species.

\section{Acknowledgements}

We thank Professor Abou Sarr (University of Paris VI, Paris, France) for his constructive suggestions, Eric Collin (CEMAGREF, France) for his valuable technical assistance, Io Skogsmyr (University of Paris Sud, Orsay, France) for reviewing the manuscript, the French Ministry for Agriculture for financing the project and the anonymous reviewer for very helpful corrections.

\section{References}

CORILLION, R. 1991. Contribution à l'étude de l'Orme (genre Ulmus L.) en Anjou. Le cas d'Ulmus laevis Pallas. Bull. Trimestriel Soc. Etudes Scientif. Anjou, 80, 4-16.

DAwson, C. D. R. 1941. Tetrasomic inheritance in Lotus corniculatus L. J. Genet., 42, 49-73.

FEDOROV, A. A. 1974. Chromosome numbers of flowering plants. Reprint by Otto Koeltz, Science Publishers, Königstein, West Germany.

GRENIER, E. 1992. Flore d'Auvergne. Société Linnéenne de Lyon, Lyon, pp. 88-89.
GUINOCHET, M. AND DE VILMORIN, R. 1973. Flore de France. Editions du C.N.R.S. Paris, 1, 209-210.

HEYBROEK, H. M. 1992. The Dutch elm breeding program. Dutch Elm Disease Workshop Recent approaches to the DED problem. Michigan State University.

JOBLING, J. AND MITCHELL, A. F. 1974. Field Recognition of British Elms. Forestry Commission Booklet 42, London.

Kerguelen, m. 1993. Index Synonymique de la Flore de France. Museum National d'Histoire Naturelle, Paris, p. 189.

KLotzsch 1855. Die Nutzanwendung der Planzenbastarde und Mischlinge. Verlandl. d. k. Preuss, Akademie Wiss, 1854, Berlin.

KREMER, A. AND PETIT, R. J. 1993. Genetic diversity in natural populations of oak species. Ann. Sci. For., 50, 186-202.

LELIVELD, J. A. 1934. Cytological studies in the genus Ulmus L. I. The supposed hybrid nature of the common Dutch elm. Genetica, 15, 425-432.

melville, R. 1975. Ulmus L. In: C. A. Stace (ed.) Hybridization and the Flora of the British Isles, pp. 292-299. Academic Press, London.

MELVILLE, R. 1978. On the discrimination of species in hybrid swarms with special reference to Ulmus and the nomenclature of $U$. minor Mill. and $U$. carpinifolia Gled. Taxon, 27, 345-351.

MITTEMPERGHER, L. AND LA PORTA, N. 1991. Hybridization studies in the Eurasian species of Elms (Ulmus spp.). Silvae Genet., 40, 237-243.

NEI, M. 1972. Genetic distance between populations. Am. Nat., 106, 282-292.

NEI, M. 1973. Analysis of gene diversity in subdivided populations. Proc. Natl. Acad. Sci. U.S.A., 70, 3321-3323.

OUAZZANI, N., LUMARET, R., VILLEMUR, P. AND DI GIUSTO, F. 1993. Leaf allozyme variation in cultivated and wild olive trees (Olea europea L.). J. Hered., 84, 34-42.

PEARCE, N. J. AND RICHENS, R. H. 1977. Peroxidase isozymes in some elms (Ulmus L.) of eastern England. Watsonia, 11, 382-383

RAELSON, J. V., LEMAITRE, P. C., STARKIE, K. M. AND GRANT, W. F. 1989. An isoenzyme study in the genus Lotus (Fabaceae). Segregation of isoenzyme alleles in synthetic allo- and autotetraploids, and in L. corniculatus. Theor. Appl. Genet., 77, 360-368.

RICHENS, R. H. 1968. The correct designation of the European field elm. Feddes Repertorium, 79, 1-2.

RICHENS, R. H. 1980. On fine distinctions in Ulmus L. Taxon, 29, 305-312.

RIChens, R. H. 1983. Elm. Cambridge University Press. Cambridge.

RICHENS, R. H. AND JEFFERS, J. N. R. 1975. Multivariate analysis of the elms of northern France. I. Variation within France. Silvae Genet., 24, 141-150.

RICHENS, R. H. AND JEFFERS, J. N. R. 1978. Multivariate analysis of the elms of northern France. II. Pooled analysis of the elm populations of northern France and England. Silvae Genet., 27, 85-95.

RICHENS, R. H. AND PEARCE, N. J. 1984. Isoperoxydase variations in Ulmus L. Forestry, 57, 75-84.

SHAW, C. R. AND PRASAD, R. 1970. Starch gel electrophoresis of 
enzymes. A compilation of recipes. Biochem. Genet.., 4, 297-320.

SHERMAN-BROYLES, S. L., BROYLES, S. B. AND HAMRICK, J. L. 1992.

Geographic distribution of allozyme variation in Ulmus crassifolia. Syst. Bot., 17, 33-41.

SOLTIS, D. E. AND SOLTIS, P. S. 1990. Isozymes in Plant Biology. T.

R. Dudley, London, pp. 5-50.

STEBBINS, G. L. 1971. Chromosomal Evolution in Higher Plants. Arnold, London.

SWOFFORD, D. AND SELANDER, R. 1989. BIOSYS-1 : a FORTRAN program for the comprehensive analysis of electrophoretic data in population genetics and systematics. J. Hered., 72, 281-283.

TOWNSEND, A. M. 1975. Crossability patterns and morpho- logical variation among Elm species and hybrids. Silvae Genet., 24, 18-23.

TUTIN, T. G. 1964. Ulmus L. In: Tutin, T. G., Heywood, V. H., Burges, N. A., Valentine, D. H., Walters, S. M. and Webb, D. A. (eds) Flora Europaea. Cambridge University Press, Cambridge.

WAPLES, K. s. 1988. Estimation of allele frequencies at isoloci. Genetics, 118, 371-384.

WIEGREFE, S. J. 1992. Molecular Genetic in the Ulmaceae: Phylogenetic Implications. Ph.D. Thesis, University of Wisconsin, Madison.

WIEGREFE, S. J., GURIES, K. P., SMALLEY, E. B. AND SYTSMA, K. J. 1993.

Genetic diversity in elms : what molecular data tell us. In: Stickle, M. B. and Sherald, J. L. (ed) Dutch Elm Disease Research, pp. 227-238. Springer, Berlin. 